University of Michigan Law School

University of Michigan Law School Scholarship Repository

Law \& Economics Working Papers

$10-16-2012$

Facebook, the JOBS Act, and Abolishing IPOs

Adam C. Pritchard

University of Michigan Law School, acplaw@umich.edu

Follow this and additional works at: https://repository.law.umich.edu/law_econ_current

Part of the Law and Economics Commons, Public Law and Legal Theory Commons, and the Securities Law Commons

Working Paper Citation

Pritchard, Adam C., "Facebook, the JOBS Act, and Abolishing IPOs" (2012). Law \& Economics Working Papers. 56.

https://repository.law.umich.edu/law_econ_current/56

This Article is brought to you for free and open access by University of Michigan Law School Scholarship Repository. It has been accepted for inclusion in Law \& Economics Working Papers by an authorized administrator of University of Michigan Law School Scholarship Repository. For more information, please contact mlaw.repository@umich.edu. 


\title{
Facebook, the JOBS Act, and Abolishing IPOs
}

\section{A two-tier market system would go a long way toward promoting capital formation and curtailing speculation.}

\author{
BY ADAM C. PRITCHARD
}

nitial public offerings (IPOs)-the first sale of private firms' stock to the public-are a bellwether of investor sentiment. Investors must be bullish if they are putting their money into untested start-ups. IPOs are frequently cited in the business press as a key barometer of the health of financial markets.

Politicians, too, see a steady flow of IPOs as an indicator that capital is fueling the entrepreneurial initiative that sustains the growth of new businesses. Growing businesses create jobs, so Republicans and Democrats can find common ground on the importance of promoting IPOs. That bipartisan consensus was on display this spring as Congress passed the JOBS Act (shorthand for "Jump-start Our Business Start-ups Act"). The JOBS Act relaxes a number of regulatory requirements viewed as stumbling blocks for private companies considering IPOs. President Obama, anxious in an election year to be seen as pro-growth, quickly signed the bill into law, notwithstanding the opposition of the Securities and Exchange Commission.

Investor sentiment can be a fickle thing, however, and the market for IPOs is notorious for its swings from peaks to valleys. That fickleness was on display with the reaction to Facebook's May 2012 IPO. That deal went from being the most anticipated since Google's IPO in 2004, to being a cautionary tale for investors. Facebook's offering price was $\$ 38$ per share, but its stock price quickly plunged in secondary market trading. Plaintiffs' lawyers promptly filed a flurry of lawsuits. An IPO drought followed as companies were reluctant to take the plunge while investors were

Adam C. Pritchard is the Frances and George Skestos Professor of Law at the University of Michigan Law School. still smarting from their Facebook losses. Congress called hearings to examine the IPO process.

Is there something fundamentally wrong with IPOs, or was Facebook an aberration?

\section{Initial Public Offerings: Bad Deals}

Unfortunately, the Facebook debacle was just a salient example of an inefficient process. Speculation and irrational exuberance, fueled by Wall Street marketing and media attention, grease the wheels for deals that have little to recommend them. Unsurprisingly, the market for IPOs falls far short of the economists' ideal of an efficient capital market.

Underpricing | Notwithstanding Facebook's disappointing secondary market performance, the more common problem with IPOs is underpricing. Underpricing is the tendency for the price of IPO stocks to rise significantly above the offering price on the first day of secondary market trading. From the perspective of the issuer, the gap between the secondary market price and the offering price reflects unexploited market demand for the company's shares-and untapped money that could help satisfy the company's capital needs. Why would issuers leave this money on the table?

Although economists have put forward a variety of theories to explain underpricing, the most plausible explanation is that the run-up reflects a speculative frenzy among retail investors who are excluded from the initial allocation in the offering. The role of 


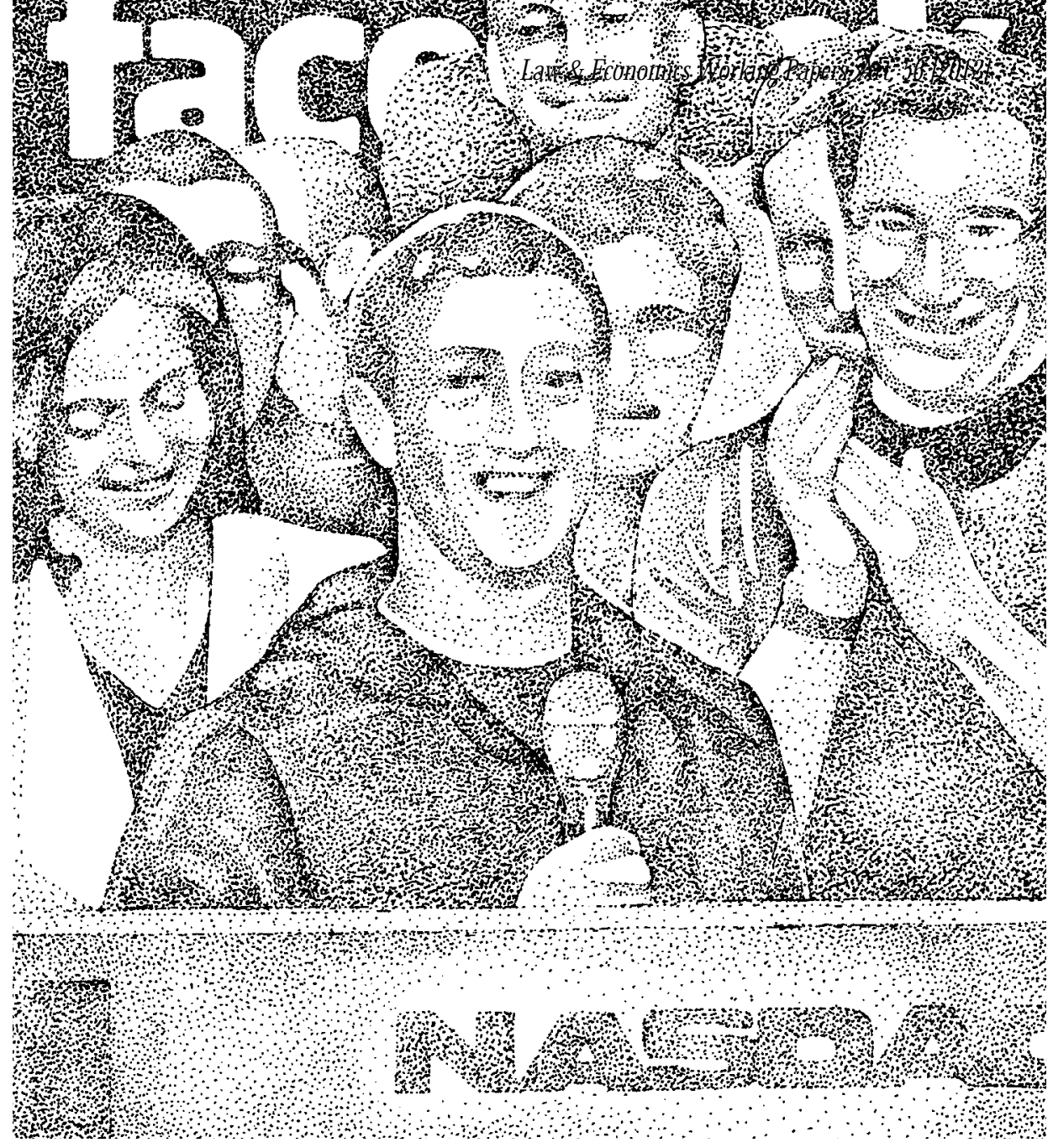

contemplated. That decision no doubt played a part in the unusually large allocation of shares to retail investors in the offering. Morgan Stanley, Facebook's underwriter, was faulted for its aggressive pricing of the stock. Nasdaq, the exchange where Facebook listed its shares, had a technological meltdown, causing a substantial number of orders to apparently disappear into the ether on the first day of trading. Most damning, however, was the revelation that analysts at a number of banks, including Morgan Stanley, had lowered their earnings projections for Facebook based on difficulties the company had disclosed with making money off of users who accessed Facebook through mobile devices. Analysts' revised estimates were shared with the banks' institutional clients, but not with retail investors. Those lowered projections fueled the institutional investors' interest in flipping their shares to retail investors as quickly as possible after the IPO. Speculative frenzy was not sufficient

speculation helps explain why traditional "book-built" offerings, in which underwriters solicit buy orders, continue to dominate auctions as a means of selling securities. Auctions, which are promoted as not leaving money on the table, have failed to attract a market following. The Achilles heel of auctions is that they offer no way of excluding the "dumb money." If retail investors are allowed to dominate pricing, institutional investors-wary of the "winner's curse" (overpaying for the shares)-will avoid the offering. Underpricing is simply the by-product of the need to exclude the undesirables from the initial pricing process.

However, book-built offerings merely move the "dumb money" into the secondary market. Once that happens, all bets are off.

Long-term underperformance $\mid$ The influx of retail traders into the secondary market, fueled by speculative enthusiasm, also explains the trend of IPOs toward long-term underperformance. Investors would be better served buying an index fund than chasing the next big thing in an IPO. Retail investors tolerate market-lagging returns overall in exchange for the possibility that one of their purchases may turn out to be the next Apple or Microsoft. Secondary market prices are driven by a lottery mentality, at least in the near term, which is not likely to lead to accurate pricing of a company's future cash flows.

Given the typical pattern of underpricing in IPOs, what explains Facebook's steep secondary market plunge? A variety of factors were identified as the culprit, with the most straightforward being the company's decision to issue 25 percent more shares than originally to sustain the secondary market price in the face of that influx of supply. The broader lesson is that the secondary market price of IPO companies can be very unstable.

If IPOs are such bad deals, why do they persist? Under current regulations, IPOs are a practical necessity. The raison d'être of IPOs is that they provide an entrée to the big leagues of public company status. That entrée is fraught with inefficiency, however, stemming from the difficulty in correctly valuing an unknown company making its first public disclosures in its offering prospectus. Without the benefit of a trading market to process the disclosure and develop a consensus valuation, mispricing in the public offering is inevitable. The bottom line is that IPOs are a failure from the perspective of both capital formation and retail investor protection.

So, is regulation to blame?

\section{The Private/Public Line}

Two Depression-era laws still provide the essential framework for securities regulation in the United States. The first enacted, the Securities Act of 1933, regulates public offerings of securities. The second, the Securities Exchange Act of 1934, regulates secondary market trading of securities, including the disclosure obligations of public companies to those markets. Despite having been enacted only a year apart, the two statutes draw the line between private and public in very different ways.

Under the Securities Act, public offerings are open to any and 
all comers. Accordingly, public offering regulations require not only extensive disclosure, but limit voluntary disclosure through a byzantine array of "gun-jumping" rules intended to curb speculative frenzies for newly issued securities. Private offerings, on the other hand, are exempted from registration with the SEC and the gun-jumping rules, but those offerings are restricted to investors who can "fend for themselves" and therefore do not need the protections afforded by registration and mandatory disclosure. The SEC has adopted the presumption that accredited investors, which include individuals with $\$ 200,000$ in annual income or $\$ 1$ million in assets, are deemed to have the requisite investment sophistication. Because they are limited to sophisticated investors, private offerings are subject to considerably less onerous disclosure requirements than public offerings. Market demands, however, dictate that some disclosure, comparable to the SEC's disclosure mandates, will be forthcoming even in private offerings.

The Exchange Act has a very different public/private dividing line. Under the Exchange Act, until recently, companies become public when they:

- listed their shares for trading on a securities exchange;

- made a registered public offering; or

- exceeded 500 record shareholders.

Companies typically trigger public company status through an initial offering of shares, with a simultaneous listing of those shares on an exchange. Companies opted for public company status when they needed capital in amounts that could only be provided by the public markets, but the decision to make an IPO frequently comes when the company is pushing the 500-shareholder limit. The problem arises because of prior private issues to employees and early-round investors.

Notably absent from these criteria for public company status under the Exchange Act was any consideration of the character of the investors. Sophisticated institutions and small retail investors were treated alike for purposes of the tally to 500. Issuers could not avoid triggering public company status by limiting their investor base to accredited investors. Unlike the Securities Act, which allows companies to sell to accredited investors in private offerings, under the Exchange Act a company had no choice but to comply with periodic disclosure requirements once it passed 500 shareholders, regardless of the sophistication of those investors.

This disconnect between the private/public standards under the two securities laws causes headaches for companies making the transition to public status, as I explain below. Facebook once again provides the illustration.

\section{Facebook's Path From Private To Public}

Facebook's path from private to public company was a rocky one. In late 2010, Goldman Sachs proposed selling a significant block of Facebook shares to institutional and other sophisticated investors via a trust that would bundle their interests in a single investment vehicle. The transaction drew attention because Facebook was at that time a private company and planning to maintain that status, at least in the short term. The bundling was an unusual feature, designed to preserve Facebook's private status by keeping the number of record Facebook investors under 500. Goldman appeared to be exploiting a loophole in the Exchange Act's 500-shareholder limit.

Whether Goldman's strategy was viable is open to debate. The SEC's rules allow shares held of record by a legal entity to be counted as one person. Thus, if broker-dealers held the shares as nominees for their customers, companies could have thousands of beneficial owners while their record books showed a number that remained under 500. The rule stipulates, however, that "[i]f the issuer knows or has reason to know that the form of holding securities of record is used primarily to circumvent" the filing requirement, "the beneficial owners of such securities shall be deemed to be the record owners thereof." That proviso suggests that the SEC would look through the legal entity to the actual owners if the issuer knows that the entity is being used to avoid public company filing.

The proposed transaction attracted considerable media attention, which led to the offering's eventual demise. The deal was pulled because of concerns that the media attention could be deemed to be a "general solicitation," which would cause the offer to become "public" and require registration. Goldman instead placed the shares in an offshore transaction.

Facebook's interaction with the private/public divide was also featured in another story that surfaced at around the same time. Word leaked that the SEC was investigating secondary trading markets for violations relating to the resale of securities issued by private companies. Facebook was among the more notable companies traded on one of these venues, SecondMarket. These markets cater mainly to employees (both current and former) of private companies, but also some early-round investors. They have experienced strong growth in recent years, but that growth was threatened by the SEC's investigation. The SEC later announced that it had reached a settlement of an enforcement action with SharesPost, SecondMarket's chief rival in this sector. The agency's complaint in that action alleged that the trading venue had been operating as an unlicensed broker-dealer, a regulatory violation.

The SEC's investigation casts a shadow over the future of private markets. In addition, these private markets, as currently structured, face substantial limits on their trading volume. SecondMarket and similar venues do not provide the liquidity afforded by an exchange, as they lack specialists and market makers, but instead simply match buyers and sellers in a central (virtual) location. These trading venues are limited to accredited investors, and the venues screen prospective investors to ensure that they qualify as accredited. These precautions help to ensure that the shares are not being "distributed" to the public, which could render the trading venue an underwriter for purposes of the Securities Act. The Exchange Act's numerical shareholder limit for private companies also poses an obstacle to further growth of these private markets. As a result, these trading venues are still dwarfed by the trading of public company shares on registered exchanges. Notwithstanding these limitations under current regulation, the growth of these 
venues suggests clear potential for expansion, if the regulatory scheme would accommodate it.

\section{The JOBS Act}

Lawmakers in Congress seized upon the salient occasion of Goldman's failed private offering of Facebook shares to attack the SEC for placing obstacles in the path of capital formation. The SEC responded in time-worn fashion, promising a review of its regulations to assess their effect on the U.S. capital markets. The SEC's delaying tactic did not work, however, as a Republican House of Representatives, anxious for an election year edge, pushed forward with the bill that would ultimately become the JOBS Act.

The private/public line $\mid$ How does the JOBS Act affect the dividing line between private and public? To begin, the act makes it easier for companies to raise capital while remaining private. It frees up the private placement process by permitting general solicitations, as long as sales are made only to accredited investors. The law also tinkers with the public company framework by raising the shareholder number to 2,000 (though no more than 500 can be non-accredited) and excluding employees from the tally. These changes should delay the point at which a growing company would be forced to become public.

These provisions might seem like a direct shot across the SEC's bow, moving the line between public and private markets so as to afford private markets more space. For the SEC, which wraps itself in the mantle of "the investor's advocate," preservation of public markets-populated by a sizable contingent of retail investors (i.e., voters)-is an existential task. The agency's political support is inextricably connected to its regulation of public markets. If the public markets ceased to exist, Congress would have little interest in funding the agency.

From another perspective, however, the JOBS Act is far from revolutionary. Congress raised the number of investors for triggering public company status under the Exchange Act, but did not challenge the notion that there should be a numerical dividing line between public and private. The JOBS Act reflects a policy disagreement between the SEC and Congress over where that line should be drawn, but it leaves intact the basic regulatory architecture of the securities markets.

Promoting IPOs $\mid$ Another key goal of the JOBS Act is to jumpstart the market for IPOs. The act loosens the gun-jumping rules by authorizing issuers to "test the waters" with institutional buyers and accredited investors prior to filing a registration statement. Companies can assess whether there is demand for the company's shares, allowing them to avoid the expense of registration if interest is lacking. In addition, the law frees securities analysts to issue research reports for new issuers during the offering process, thereby promoting demand for the company's shares.

The JOBS Act also encourages IPOs by easing the burden of accounting fees for newly public companies and reduces the audited financial statement requirement for IPOs to only two years. Post-IPO companies also are exempted from Section 404 of the Sarbanes-Oxley Act, which requires auditor assessment of a company's internal controls, for five years. That exemption disappears, however, after the company reaches $\$ 1$ billion in annual revenue. Nonetheless, companies that go public should see substantially reduced auditors' fees, at least in the short run.

Junior-varsity public companies? | For companies still unwilling to face the burdens of full public company status, Congress gave the SEC new authority to exempt offerings from the ordinary registration requirements, raising the limit for such offerings from $\$ 5$ million to $\$ 50$ million. Along with that exemptive authority, Congress authorized the SEC to adopt less demanding periodic disclosure from companies using this new offering exemption. Moreover, Congress also stipulated that the securities sold pursuant to this exemption be unrestricted, i.e., they could be freely resold to retail investors.

This new exemption has the potential to be a game changer, creating a potential lower tier of public companies, thus blurring the line between public and private. However, the creation of a public company incubation pool is only a possibility, as it is easy to see the SEC dragging its heels in implementing this exemption. Certainly nothing will happen at the SEC anytime soon. The agency is still struggling to get out from under a rulemaking backlog created by the Dodd-Frank Act passed in 2010. After the 2012 election, with the spotlight from Capitol Hill perhaps less glaring, the SEC may feel that it has a freer hand in imposing substantial requirements when it eventually promulgates the exemption. The SEC may strangle the JOBS Act offering exemption in its crib.

\section{Abolishing IPOs}

The public/private dividing line is on shaky ground. With the JOBS Act, Congress has pushed back the public line for both the Securities Act (by eliminating the general solicitation ban for private offerings) and the Exchange Act (by raising the number of shareholders triggering public company status). But the JOBS Act fails to address the fundamental inefficiency of the market for IPOs.

In this section, I propose an alternative to IPOs-the current transition point between private and public-that deals with that inefficiency. The foundation of my proposal rests on two central premises:

- IPOs are an inefficient means of capital formation.

- Private markets, if freed up to continue expanding their pools of liquidity, can satisfy the capital needs of growing companies until they are ready for the burdens of being a public company.

Under my proposal, companies would go up-and downbetween the private and public markets as warranted. Any company reaching a certain quantitative benchmark would be eligible 
for elevation to the public market. If a company opted for public status, it would have to satisfy the periodic reporting obligations of the Exchange Act for as long as it remained public. I explain below how the process might work.

The private market | Issuers below the quantitative benchmark would be limited in their access to both the primary and secondary markets. Their securities could be sold in private offerings only to accredited investors. In contrast to current practice, however, those securities could not be freely resold after a minimum holding period. Instead, the issuer would be required to limit transfer of those shares to accredited investors until it became a public company. Accredited investors could freely resell the securities amongst themselves.

I anticipate organized markets for private trading along the lines of SecondMarket and SharesPost. These private markets would need the issuer's consent for the trading of their shares, a form of quasi-listing. Only certified accredited investors would be allowed to participate. The private trading market would be responsible for screening prospective investors to ensure that they meet the SEC's criteria. This accredited investor category includes mutual funds, so retail investors could access exposure to this private market, albeit only through a diversified vehicle administered by a regulated investment manager.

The question of disclosure in the private market poses a challenging issue. It would defeat the market's purpose to require the disclosure expected of a public company. On the other hand, some standardization of disclosure practices would likely benefit both investors and issuers. And the size of today's private offerings raises the possibility of a collective action problem for investors, making it difficult for them to negotiate with the issuer for contractual representations and warranties. There are some fundamentals hard to imagine doing without, such as audited financial statements. Beyond that baseline, however, are a range of difficult questions regarding materiality. One possibility would be to allow private markets to establish disclosure requirements pursuant to their listing agreements, with those listing agreements subject to SEC approval. Such an arrangement would afford flexibility and responsiveness to market forces, while still giving the SEC authority to ensure that disclosure standards did not fall too far.

The public market | Elevation to the public market would be voluntary in my scheme. Issuers that were not prepared to handle the burden of public company obligations could limit the transfer of their shares to the private market. If a company felt that it could satisfy its capital needs in the private market, it would be free to remain there.

Companies would graduate to the public market based on the value of their common equity. One possible benchmark would be $\$ 75$ million in market capitalization, a threshold currently used by the SEC for streamlined "shelf" registration. A company electing to move to the public market would initiate the process by filing a Form 10-K (annual report) with the SEC. Its shares would then continue to trade in the private market for a season- ing period with the filing of requisite 10-Qs (quarterly reports). The prices in the private market would now be informed by full SEC-mandated disclosure. After the seasoning period, accredited investors would be able to sell their shares in the public market. This opportunity would be available whether the accredited investor had purchased their shares from the company or from other accredited investors in the private trading market. That public market could be an exchange if the company chose to list, or the over-the-counter market. Either way, the trading price in the public market would be informed by the prior trading in the private market, as well as the new information released in the company's $10-\mathrm{K}$ and $10-\mathrm{Q}$.

There are some questions concerning the private market seasoning period before public trading would be permitted. It would not be practicable to limit companies from any sales during the seasoning period; capital needs do not go away simply because the company is making the transition to public status. Indeed, the need for capital is presumably pushing the company to bear the burdens of public status. This creates the risk that companies could use investment banks or other intermediaries, such as hedge funds, as conduits during the seasoning period. This strategy is limited, however, by the fact that the intermediaries could only sell the shares to other accredited investors during the seasoning period, thereby limiting the chance that the shares would be dumped on retail investors. Moreover, unless the company has very pressing capital needs, it is unlikely to accept much of a liquidity discount for its shares, which it will be able to freely sell after the seasoning period expires. It might be necessary, however, to impose volume limits on sellers in the public markets during a post-seasoning transition period to allow the trading market to develop. A quick dump of shares immediately after the seasoning period expired has the potential to reproduce the inefficient pricing and irrational speculation that taints the current market for IPOs.

Only after the company graduated to having its shares traded in the public secondary market would the company be allowed to sell securities to public investors. What form should sales of public equity by the issuer take? The logic of my proposal, with its preference for the superior informational efficiency of trading markets, suggests that issuers selling equity should be limited to at-the-market (ATM) offerings. Issuers would sell directly into the public trading market instead of relying on an underwriter to identify (create?) demand. This approach puts its faith in markets, rather than salesmen, for efficient pricing.

Unfortunately, this strategy has its limits. ATM offerings are a rapidly growing portion of seasoned equity offerings, but their volume is still dwarfed by traditional book-built offerings. Particularly for larger offerings, the liquidity of the secondary trading market may be insufficient to absorb the newly issued shares. Indeed, even book-built offerings would be substantially constrained by the existence of a market price. Could we nudge issuers toward ATM offerings without mandating them?

One possibility would be to eliminate the Securities Act's strict liability standards for ATM offerings, while retaining it for underwritten offerings. At a minimum, it makes little sense to impose 
underwriter liability on the broker-dealers hired by issuers to manage ATM offerings. If large volumes need to be "sold, not bought," the opportunities for abuse come in the selling process, and ATM offerings are not "sold." The SEC's enforcement efforts would be needed to ensure that there were no backdoor selling efforts to prime the market for an ATM offering. Even for the issuer, the draconian threat of the Securities Act's strict liability seems excessive for an ATM offering. ATM offerings-if genuinely issued into a pre-existing market without solicitation-do not really require a registration statement or a prospectus; at most they need to file an 8-K with the SEC announcing the number of shares to be offered, followed by another 8-K disclosing the number actually sold. Anti-fraud concerns could be addressed by the Exchange Act's less draconian Rule 10b-5.

Relegation | If there are private companies wanting to rise to the public level, it follows that there will be public companies anxious to shed the burdens of public status. An important benefit of a two-tier market is that retail investors would not be cut off completely from liquidity if a company chooses to relegate itself to the private market. There is no reason to preclude retail investors from selling their shares in the private market, even if they would be barred from purchasing shares in companies that dropped to private status. Moreover, there is little to be gained by prohibiting companies from exiting the public pool; a restrictive approach will simply discourage companies from pursuing public company status in the first place. On the other hand, too easy an exit may invite abuses.

To check manipulative schemes, I would mandate a shareholder vote with the usual required disclosures before a company would be permitted to drop from public to private status. A vote would not trap companies that have struggled after going public, but it would require the company to persuade its shareholders that the benefits of public company status were no longer worth the candle.

Objections | Would an expanded private market open the door to fraud and manipulation? The short answer is that as long as people are infected by the love of money, fraud will always be with us. Given that sad fact of human nature, we should funnel transactions to the venues that make it most difficult to get away with fraud, and trading markets provide a critical check against fraud. To be sure, the private market proposed here is likely to have a higher incidence of fraud and manipulation than the public market. But the scope of that fraud will necessarily be limited by the smaller size of the private markets relative to their public counterparts. Moreover, the entities sponsoring trading in those private markets will have competitive incentives to take cost-effective measures to discourage fraud; discouraging fraud will encourage investor participation. SEC enforcement would remain available to counter the most egregious abuses.

The potential for abuse in the private market has to be weighed against reductions in fraud elsewhere. In particular, my seasoning

period requirement substantially reduces the opportunities for fraud by companies entering the public market. On balance, the overall incidence of fraud may be less. And retail investors, who are least able to bear it, will almost certainly be exposed to less fraud. At the same time, capital formation-efficient allocation of capital to cost-justified projects-will be enhanced.

\section{Conclusion}

The conspicuous flaws with IPOs suggest that we should put an end to them, if we can establish a viable alternative. In my view, restrictions on private markets have hindered that viable alternative from emerging until now. In particular, private markets such as SecondMarket and SharesPost have been hamstrung by the 500-shareholder limit triggering public company status. The JOBS Act's increase to 2,000 shareholders for public company status promises to bolster the liquidity of private markets, making them a robust alternative for growing companies.

This newly available liquidity is the lynchpin of my argument that we should replace IPOs with a two-tier market system. Issuers choosing to make the transition to the public market would be required to file periodic disclosures with the SEC for an appropriate seasoning period, which would replace the IPO as the rite of passage to becoming a public company. Only after the seasoning period would the issuer be allowed to sell shares to the public at large. Such a regime would allow the secondary market to process an aspiring public company's disclosure prior to any sales to the public and allow investors to arrive at a well-informed consensus valuation. This regulatory framework would go a long way toward promoting efficient capital formation and curtailing speculation. A happy by-product would be more vigorous investor protection for unsophisticated investors. Does anyone think that retail investors would be harmed if we eliminated IPOs?

With the passage of the JOBS Act, change is coming to the demarcation between private and public status under the securities laws. Will the SEC attempt to obstruct this change, or embrace it in an effort to promote greater capital formation? My proposal affords the SEC an opportunity to promote capital formation while also enhancing investor protection. The two-tier private/public market scheme outlined here would harness private markets to promote the public good while simultaneously eliminating the public bad of initial public offerings.

\section{READINGS}

n- "A Review of IPO Activity, Pricing, and Allocations," by Jay R. Ritter and Ivo Welch. Journal of Finance, Vol. 57, No 4 (2002).

- "Counterspeculation, Auctions, and Competitive Sealed Tenders," by William Vickrey. Journal of Finance, Vol. 16, No. 1 (1961).

- "Facebook Drives SecondMarket Broking \$1 Billion Private Shares," by Richard Teitelbaum. Bloomberg
Markets Magazine, April 27, 2011.

- " “Hot Issue' Markets," by Roger G. Ibbotson and Jeffrey F. Jaffe. Journal of Finance, Vol. 30, No. 4 (1975).

n- "Inefficiency in the Market for Initial Public Offerings," by Jonathan A. Shayne and Larry D. Soderquist. Vanderbilt Law Review, Vol. 48 (1995).

n- "Underwriter Price Support and the IPO Underpricing Puzzle," by Judith S. Ruud. Journal of Financial Economics, Vol. 34, No. 2 (1993). 